\title{
Palaeocopida (Ostracoda) across the Permian-Triassic events: new data from southwestern Taurus (Turkey)
}

\author{
SYLVIE CRASQUIN-SOLEAU ${ }^{1}$, JEAN MARCOUX $^{2}$, LUCIA ANGIOLINI $^{3}$ \& ALDA NICORA ${ }^{3}$ \\ ${ }^{1}$ CNRS, FR32, Université Pierre et Maris Curie, T. 46-56, E.5, case 104, 75252 Paris cedex 05, France (e-mail: crasquin@ccr.jussieu.fr). \\ ${ }^{2}$ Université Denis Diderot, Sciences Physiques de la Terre, T. 24-25, E.1, 75005 Paris, France (e-mail: marcoux@ipgp.jussieu.fr). \\ ${ }^{3}$ Universitat di Milano, Dipartimento di Scienze della Terra, via Mangiagalli 34, 20133 Milano, Italy (e-mail: lucia.angiolini@unimi.it; \\ alda.nicora@unimi.it).
}

\begin{abstract}
The Palaeocopida have been considered as an entirely Palaeozoic group and their disappearance as a marker for the Palaeozoic-Mesozoic boundary. Despite this, 11 Palaeocopida species have been recorded in the Early Triassic. New data obtained in southwestern Taurus at the PermianTriassic section of Çürük dağ, permit an assessment of this problem. This paper synthesizes the data on lowermost Triassic ostracodes and revises the youngest Palaecopida occurrences. A new Early Triassic Palaeocopida species is described (Reviya curukensis n. sp.). J. Micropalaeontol. 23(1): 67-76, May 2004.
\end{abstract}

\section{INTRODUCTION}

For all marine biota, the end-Permian mass extinction is the most dramatic event of the Phanerozoic. At the end of the Permian, $49-57 \%$ of marine families, $83 \%$ of genera and $96 \%$ of species disappear (Sepkoski, 1992; Erwin, 1993; Jablonski, 1994; Benton, 1995; Lethiers 1998; note that the figures vary according to author).

As with other marine organisms, benthic ostracods are subject to the effects of calamitous events (among others, the great end-Permian regression followed by the quick and dysoxic Lower Triassic transgression, the modifications of climates and oceanic circulation, the salinity drop, the volcanism, linked with Pangea assemblage; synthesis in Lethiers, 1998).

The Early Triassic marine ostracods are poorly known. Some species have been mentioned, in greater or less detail, from the Early Triassic (Induan-Olenekian) of northwestern Australia (Jones, 1970), Pakistan (Sohn, 1970), the Precaspian Depression (Schneider 1948, 1960; Kukhtinov \& Crasquin-Soleau, 1999), Nepal (Kozur, 1971), Kashmir (Agarwal, 1979, 1980, 1981), the Germanic Basin (Kozur, 1972), Israel (Hirsch \& Gerry, 1974), South China (Wang, 1978; Wei, 1981; Hao, 1992, 1994) and Greece (Crasquin-Soleau \& Baud, 1998).

The Çürük dağ section $\left(\mathrm{N} 36^{\circ} 41^{\prime} 32-\mathrm{E} 30^{\circ} 27^{\prime} 40\right)$ is located in western Taurus, in the Antalya Nappes (Turkey), SW of Antalya (Fig. 1) (Lys \& Marcoux, 1978; Crasquin-Soleau et al., 2002). The Pamucak Formation (Middle-Upper Permian) is overlain by the Kokarkuyu Formation (Lower Triassic) (Lys \& Marcoux, 1978; Marcoux \& Baud, 1986). In the Çürük dağ section (Fig. 1), the Pamucak Formation is a thick (400-600 m) succession of inner to outer platform facies (Capitanian to Changhsingian; dating by Foraminifera and calcareous algae; Lys \& Marcoux, 1978; Marcoux \& Baud, 1986). The lowest Triassic levels are rich in Induan Foraminifera (Ammodiscus, Rectocornuspira, Cyclogira, Earlandia) and rare in conodonts (Isarcicella isarcica staeschei (Dai \& Zhang) and Hindeodus parvus (Kozur \& Pjatakova)) (Crasquin-Soleau et al., 2002). This association is an index of the second conodont Triassic biozone (Lai \& Mei, 2000).

In the Upper Permian samples, the ostracod assemblage is similar to other Middle and Upper Permian assemblages observed in the Palaeo-Tethys (see, for example, Crasquin-
Soleau \& Baud, 1998; Crasquin-Soleau et al., 1999). It is mainly made up of Bairdiacea (Bairdia, Petasobairdia, Acratia, Fabalicypris, Liuzhinia, Macrocypris, Baschkirina, Microcheilinella), with a minor amount of Quasillitacea (Graphiodactyllis?), Cavellinacea (Sulcella) and Cypridacea (Basslerella, Arqoviella?, Callicythere). The Palaeocopida are represented by genera common in the Palaeo-Tethys, such as Hollinella, Knoxiella, Permoyoungiella and Sargentina. The ostracod assemblage is characteristic of a marine platform environment, deposited under a tropical climate.

In the basal beds of the Kokarkuyu Formation (Lower Triassic), the ostracods are represented by Bairdiacea (mainly the genera Bairdia, Bairdiacypris, Liuzhinia), Cavellinacea (Sulcella?) and by Palaeocopida (Kirkbyacea, Reviya curukensis n. sp., and an undetermined Paraparchitacea). This assemblage, which has a lower specific and generic diversity than the assemblages observed in the Upper Permian beds, seems to indicate a shallower environment and/or with salinity variations, always under a tropical climate.

It has long been thought that the Palaeocopida (ostracods with a straight dorsal border) became extinct during the Permian and their presence was considered as an index of Palaeozoic age. However, Palaeocopida have been reported from the Early Triassic of Pakistan (Olenekian), Australia (Induan), South China (Induan and Olenekian) and Hungary (Late Early Induan) (Table 1, with references).

Ostracods of the lower part of the Kokarkuyu Formation in the Çürük dağ section are the oldest Triassic forms figured and described to date, coming from the parvus and staeschei Biozones. The Palaeocopida, Kirkbyacea, here discovered, are the youngest observed outside of South China and Pakistan. Ostracodes were mentioned in the lowermost Triassic of Dolomites (Werfen Formation, Italy) by Broglio Loriga et al. (1986), but they have never been studied.

Furthermore, these findings are very important in the understanding of a critical aspect of the end-Permian mass extinction - the anomalous pattern of the post- extinction recovery, which seems to be significantly delayed for most clades (Erwin, 1998; Twitchett, 1999; Rong \& Shen, 2002). Even if the ostracod assemblage at the base of the Kokarkuyu Formation shows a low specific and generic diversity, it increases the 

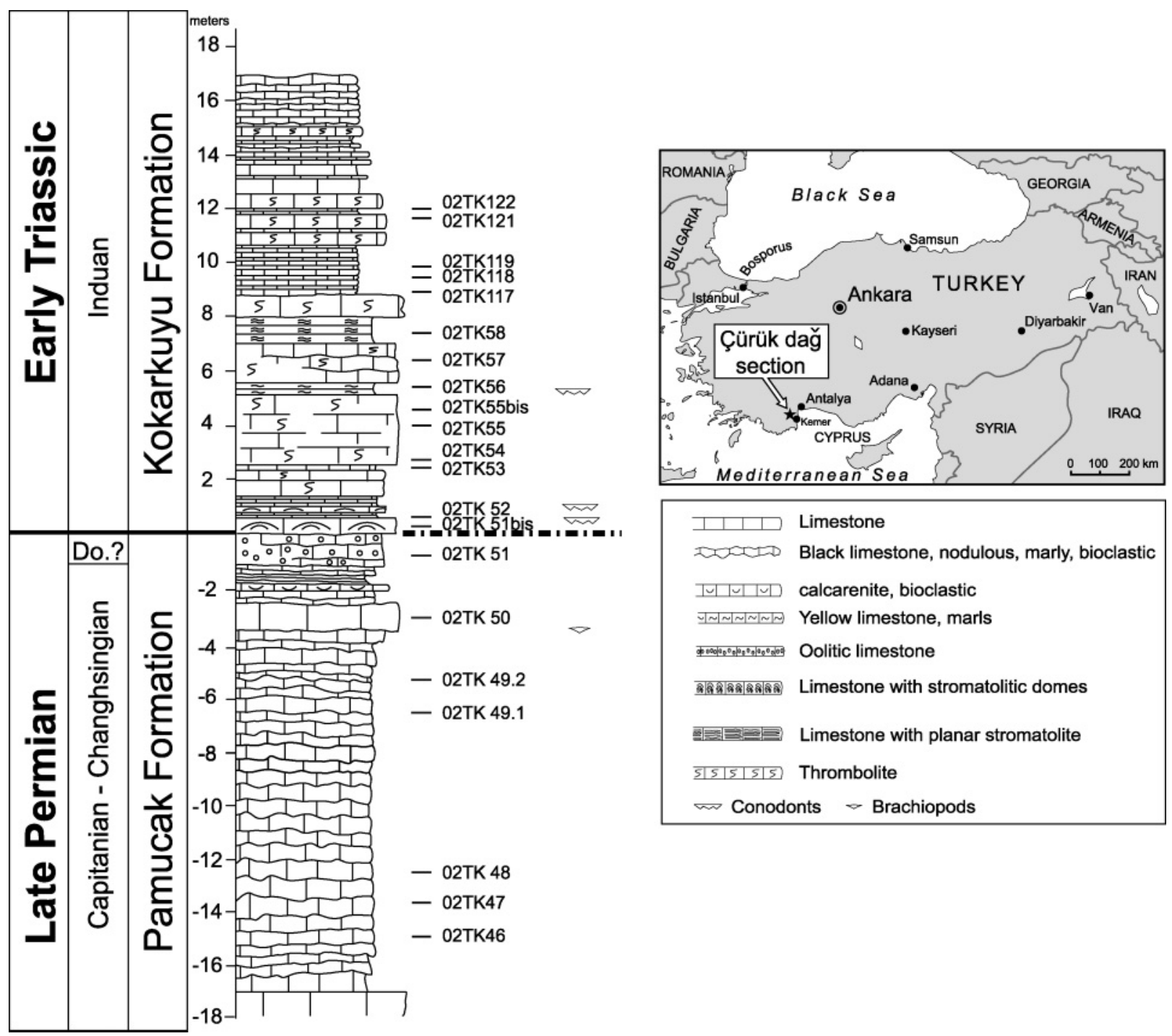

\begin{tabular}{|c|c|}
\hline \begin{tabular}{l|l|l|l|l|l} 
& 1 &
\end{tabular} & Limestone \\
\hline DWDD & Black limestone, nodulous, marly, bioclastic \\
\hline 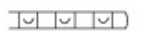 & calcarenite, bioclastic \\
\hline 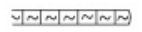 & Yellow limestone, marls \\
\hline 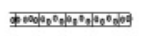 & Oolitic limestone \\
\hline 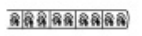 & Limestone with stromatolitic domes \\
\hline 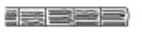 & Limestone with planar stromatolite \\
\hline S|S|S|l|s|s & Thrombolite \\
\hline$\varpi$ Conodc & nts $\propto$ Brachiopods \\
\hline
\end{tabular}

Fig. 1. Çürük dağ section, with location of ostracod-bearing samples.

number of Lower Triassic ostracods known, with the occurrence of 12 species, one of which - at least - is new. This could suggest that there are places - free from low oxygen restriction - where the recovery of benthic groups was more rapid.

\section{PALAEOCOPIDA ACROSS THE PERMIAN-TRIASSIC BOUNDARY}

In 1961, in the 'Treatise of Invertebrate Paleontology - Part Q: Ostracoda' (Moore, 1961), the order Palaeocopida Henningsmoen, 1953 was reported to range from the Early Ordovician to the Middle Permian. Scott (in Moore, 1961) defined the Palaeocopida as follows: 'dorsal margin long and straight; surface smooth or ornamented; lobes, sulci, ventral and adventral structures common; calcareous inner lamella absent; dimorphic or non-dimorphic; soft parts unknown'. They are marine.

In the Treatise, the stratigraphic range was questionably extended up to Recent because the superfamily Punciacea is referred, with doubt, to this order. Kozur (1993) erected a new order, the Reticulocopida (Ordovician-Recent), bringing the Palaeozoic Kirkbyacea and Late Cretaceous-Recent Punciacea together. The problem of relationships between Kirkbyacea and Punciacea was discussed by Becker (1997 with previous references). Kozur (1998) published new Upper Triassic Punciacea genera and species which are, in his opinion, the missing link between the Punciacea and Kirkbyacea. Horne et al. (2002) confirmed that the Punciacea belong to the Palaeocopida with a few genera such as Manawa and Promanawa. In both cases, this is a Palaeozoic order with isolated Recent representatives, with a great gap during almost all of the Mesozoic, due to the lack of data during this time interval.

\section{Middle and Late Permian Palaeocopida}

Since 1961, numerous papers have been published with reference to Middle and Late (International scale - decision of IUGS (Beijing, 1996) and taken up by Waterhouse (1997)) Permian ostracods. Table 2 lists some of the papers where Palaeocopida were described and/or reported (not an exhaustive list). 
Turkish Permian-Triassic event ostracods

\begin{tabular}{|c|c|c|c|c|c|c|c|c|c|}
\hline Authors & $\begin{array}{l}\text { Sohn } \\
(1970)\end{array}$ & Jones (1970) & $\begin{array}{l}\text { Zheng } \\
(1976)\end{array}$ & $\begin{array}{l}\text { Wang } \\
(1978)\end{array}$ & $\begin{array}{l}\text { Wei Ming } \\
\text { (1981) }\end{array}$ & $\begin{array}{l}\text { Kozur } \\
(1985)\end{array}$ & $\begin{array}{l}\text { Hao } \\
(1992)\end{array}$ & $\begin{array}{l}\text { Hao } \\
(1994)\end{array}$ & $\begin{array}{l}\text { Crasquin- } \\
\text { Soleau et } \\
\text { al. (2002, } \\
\text { and this } \\
\text { paper }\end{array}$ \\
\hline Palaeocopid species and location & $\begin{array}{l}\text { Late } \\
\text { Induan - } \\
\text { Early } \\
\text { Olenekian } \\
\text { Salt Range } \\
\text { (Pakistan) }\end{array}$ & $\begin{array}{l}\text { Induan } \\
\text { Perth Basin } \\
\text { (Australia) }\end{array}$ & $\begin{array}{c}\text { Early } \\
\text { Mesozoic } \\
\text { (SW } \\
\text { China) }\end{array}$ & $\begin{array}{c}\text { Early } \\
\text { Induan } \\
\text { W } \\
\text { Guizhou } \\
\text { and NE } \\
\text { Yunnan } \\
\text { (South } \\
\text { China) }\end{array}$ & $\begin{array}{l}\text { Induan - } \\
\text { Olenekian } \\
\text { Sichuan } \\
\text { (South } \\
\text { China) }\end{array}$ & $\begin{array}{l}\text { Late early } \\
\text { Induan } \\
\text { Bükk Mts } \\
\text { (Hungary) }\end{array}$ & $\begin{array}{l}\text { Induan } \\
\text { Guizhou } \\
\text { (South } \\
\text { China) }\end{array}$ & $\begin{array}{l}\text { Induan } \\
\text { Guizhou } \\
\text { (South } \\
\text { China) }\end{array}$ & $\begin{array}{c}\text { Early } \\
\text { Induan } \\
\text { Çürük } \\
\text { dağ } \\
\text { (Turkey) }\end{array}$ \\
\hline $\begin{array}{c}\text { Carinaknightina carinata } \\
\text { Sohn, } 1970\end{array}$ & & & & & & & & & \\
\hline $\begin{array}{l}\text { C. discarinata } \\
\text { Sohn, } 1970\end{array}$ & & & & & & & & & \\
\hline $\begin{array}{c}\text { C. neutrum } \\
\text { (Jones, 1970) }\end{array}$ & & $\begin{array}{l}\text { Praegium } \\
\text { neutrum }\end{array}$ & & & & & & & \\
\hline $\begin{array}{c}\text { C. zhenfengensis } \\
\text { Hao, } 1992\end{array}$ & $\begin{array}{l}=C . \text { aff } \\
\text { carinata }\end{array}$ & & & & & & & & \\
\hline $\begin{array}{l}\text { Hollinella tingi } \\
\text { (Patte, 1935) }\end{array}$ & & & & & & & & & \\
\hline $\begin{array}{c}\text { Hollinella unispinata } \\
\text { Hao, } 1992\end{array}$ & & & & & & & & & \\
\hline $\begin{array}{c}\text { Hollinella sp. sensu } \\
\text { Jones, } 1970\end{array}$ & & & & & & & & & \\
\hline $\begin{array}{l}\text { H. cf. plana Jiang, } 1983 \\
\text { sensu Hao, } 1992\end{array}$ & & & & & & & & & \\
\hline $\begin{array}{l}\text { H. cf. tingi (Patte, 1935) } \\
\text { sensu Hao, } 1992\end{array}$ & & & & & & & & & \\
\hline $\begin{array}{c}\text { Langdaia suboblonga } \\
\text { Wang, } 1978\end{array}$ & & & & & & & & & \\
\hline $\begin{array}{c}\text { Roundyella? papilliformis } \\
\text { Wang, } 1978\end{array}$ & & & & & & & & & \\
\hline Reviya curukensis n.sp. & & & & & & & & & \\
\hline
\end{tabular}

Grey boxes, papers where the species is described and/or figured and/or mentioned; crossed boxes, papers where the species is regarded as crossing the Permian-Triassic boundary.

Table 1. Early Triassic palaeocopid species in literature.

Reference

Hamilton $(1942 *)$

Schneider (1948, 1960), Kotschetkova $\left(1959^{*}\right)$

Ishizaki (1964)

Belousova (1965)

Krömmelbein (1958), Knüpfer (1967), Ivanov (1975), Woszczyńska (1987)

Khivintseva (1969)

Sohn (1970)

Bless \& Jordan (1972)

Zalanyi (1974), Kozur (1985a, 1985b, 1991)

Wang (1978)

Chen \& Shi (1982)

Shi \& Chen (1987)

Gerry et al. (1987)

Lethiers et al. (1989)

Becker \& Wang (1992)

Kolar-Jurkovšek \& Jurkovšek (1995)

Olempska \& Blaszyk (1996)

Gramm (1997)

Crasquin-Soleau \& Baud (1998)

Crasquin-Soleau et al. (1999, 2001), Angiolini et al. (2003), Crasquin-Soleau (2003)

*Papers published before the Treatise but not taken into account in it.

Table 2. Sources describing Palaeocopida from the Middle and Late Permian.
Geographical area/comment

North American Platform

Russian Platform

Japan

Armenia

Zeichstein - Central Europe

Southwestern Russian Platform

West Pakistan

Synthesis on Hollinellidae Family

Bükk Mountains (Hungary)

South China (Guizhou and Yunnan)

South China (Jiangsu and Hubei)

South China (Meishan)

Israel

Tunisia

China

Slovenia

Spitsbergen

Far Eastern Russia

Greece

Interior Oman 
S. Crasquin-Soleau et al.
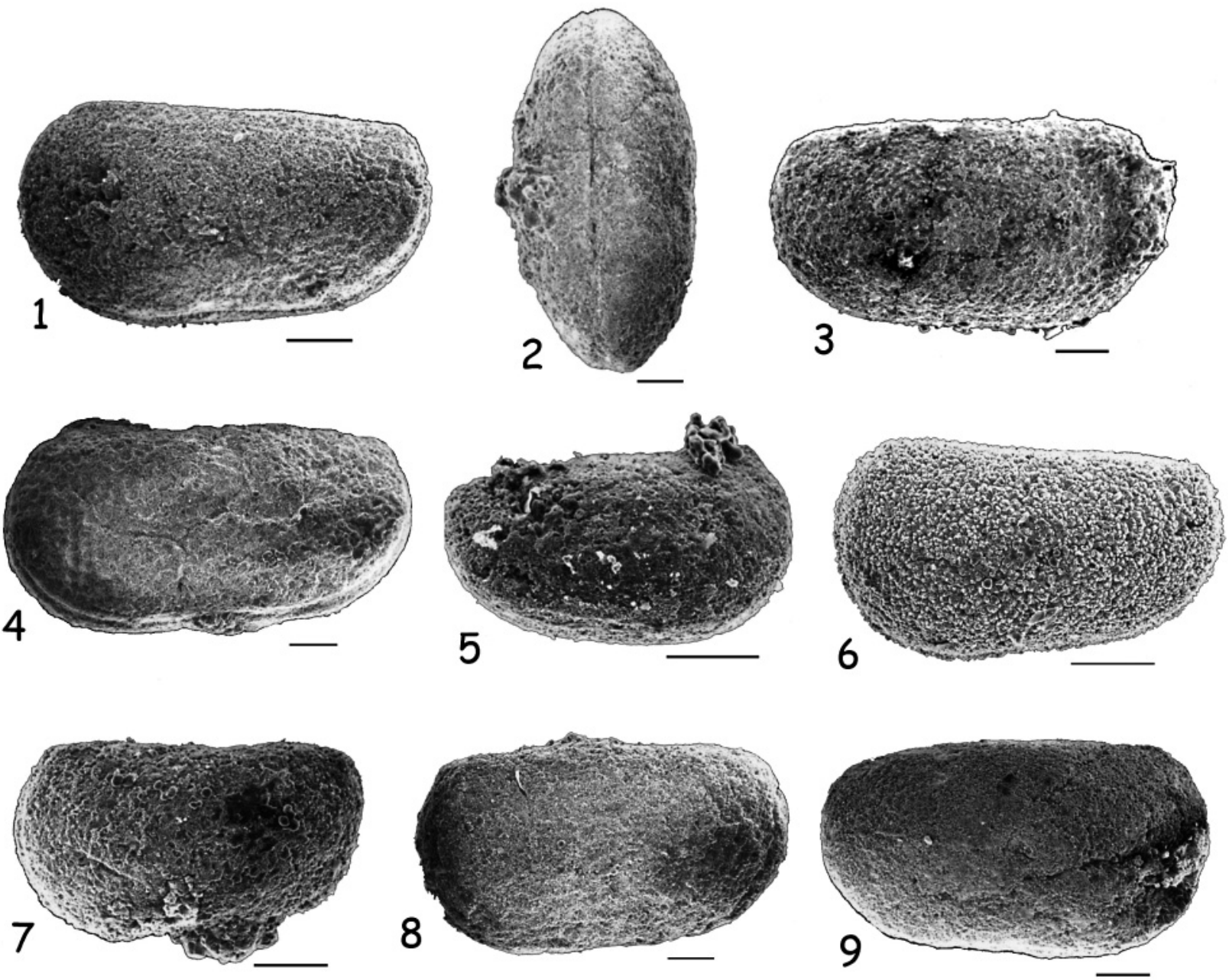

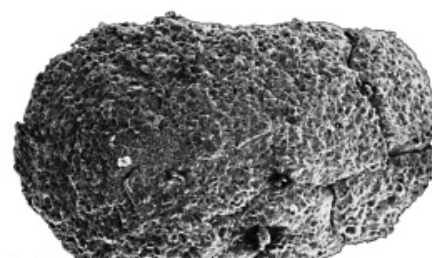

$10+2=$
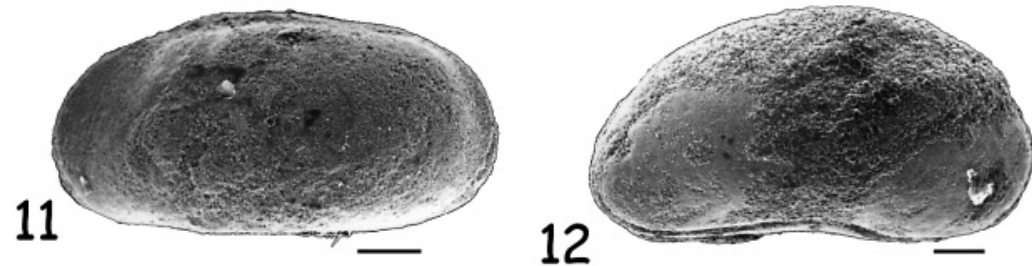
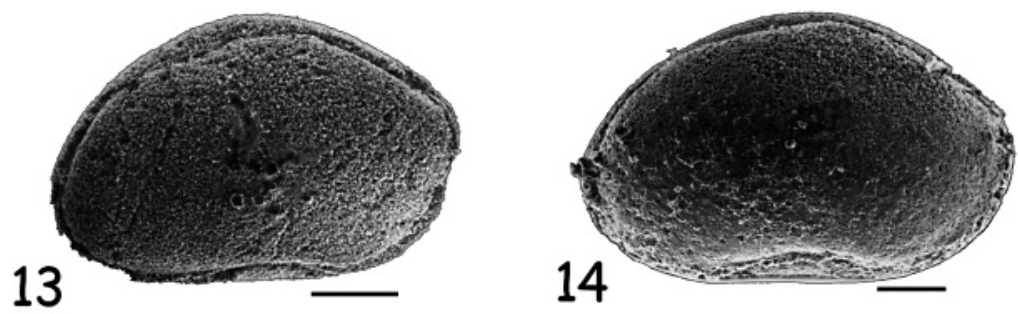


\section{Early Triassic Palaeocopida}

Belousova (1965) described the ostracod fauna of the Late Permian (Dzulfian=Wuchiapingian)-Early Triassic (Induan) from Dzhulfa section (Armenia). She figured 26 species, among which, 19 are new. In this paper, eight species cross the Permian-Triassic boundary. She reported two species of Palaeocopida in the Early Triassic: Amphissites notabilis Belousova, 1965 and Hollinella cushmani Kellett, 1933; this last species is a junior synonym of Hollinella bassleri (Kellett, 1928) (Bless \& Jordan, 1972). Chao (1965) and Tozer (1967) considered this part of the section to be latest Permian.

In 1970, Sohn published the marine ostracod fauna (13 species belonging to ten genera) from the Early Triassic of the Salt and Sugar Ranges (West Pakistan). Particularly, the Palaeocopida Carinaknightina carinata Sohn, 1970, Carinaknightina aff. carinata Sohn, 1970, Carinaknightina discarinata Sohn, 1970 and Kirkbyidae gen. spp. indet. are described.

In 1970, Jones presented the Early Triassic ostracods from the Perth Basin (Western Australia). He recognized a new species, Praegnium neutrum Jones, 1970, which belongs to the genus Carinaknightina erected the same year by Sohn (1970). This species and Hollinella sp. are the two palaeocopids occurring in the Early Triassic of the Perth Basin.

In 1976, Zheng published a paper on Early Mesozoic ostracods from Southwestern China and recognized Hollinella tingi (Patte, 1935) in the Early Triassic.

Wang (1978) found two Palaeocopida in the Early Triassic of the southern border of South China: Hollinella tingi and a species of a new genus Langdaia suboblonga Wang, 1978. Wei (1981) recovered these two species from the Early Triassic of the Sichuan (South China).

Kozur (1985a) defined ostracod assemblage zones with biostratigraphic value in the Late Palaeozoic-Early Triassic of the Bükk Mountains (Hungary). According to that author, Hollinella tingi s.s. (this sensu stricto is not explained) occurs in Europe, associated with Isarcicella isarcica (conodont index of the second biozone of Triassic/Induan/Griesbachian) and in China in Ophiceras-bearing beds (Griensbachian). He considered the base of the Hollinella tingi assemblage zone as 'a good marker for the Permo-Triassic boundary'. He defined the lower and the upper boundaries of the assemblage zone by the appearance and the disappearance of Hollinella tingi (Kozur, 1985a: 239).

In 1992, Hao presented 11 species from the Early Triassic from Guizhou (South China); he described three new species, two Palaeocopida among them: Hollinella unispinata Hao, 1982 and Carinaknightina zhenfengensis Hao, 1982 (synonym of Carinaknightina aff. carinata sensu Sohn, 1970) associated with the following Palaeocopida: Carinaknightina carinata, Hollinella tingi, Hollinella cf. plana Jiang, 1983, Hollinella cf. tingi and Langdaia suboblonga.

In conclusion, in the literature 11 Palaeocopida species belonging to five genera are considered to occur in the Early Triassic (Table 1).

In the Çürük dağ section, the authors have recognized two new Palaeocopida in the earliest Triassic. One species is described below (Reviya curukensis $\mathrm{n}$. $\mathrm{sp}$. Crasquin-Soleau). The other one is more problematic and the attribution should be taken with caution (Paraparchitidae sp. indet.) due to poor preservation of the material (Pl. 1, fig. 10).

\section{Palaeocopida across the Permian-Triassic boundary}

In the literature, three Palaeocopida species were reported to cross the Permian-Triassic boundary: Hollinella tingi, Hollinella unispinata and Roundyella? papilliformis Wang, 1978 (Table 3). Podocopid species - Fabalicypris reniformis (Chen, 1958) (Bairdiacea) and Basslerella obessa Kellett, 1935 (Cytheracea) are recognized by Hao $(1992,1994)$ to survive to the mass extinction. These two species were not found in the Çürük dağ section and are not discussed further. On the other hand, Bairdia subsymmetrica (Shi, 1987), described in the Changsingian of Meishan (South China) (Shi \& Chen, 1987), is present in the earliest Triassic of the Kemer area (Pl. 1, figs 13-14), thus, crossing the Permian-Triassic boundary.

Hollinella tingi was described as Beyrichia tingi by Patte (1935), from the Early Permian T'ungstzu and Takuhesinch'ang Districts of South China. The preservation is poor and it was described based on external moulds on sample surfaces. According to Bless \& Jordan (1972), this species is very poorly known.

In 1954, Hou recognized this species in the Upper Permian black shales of the Chihsia Formation (Western Hupei, South China). Hou described cardinal spines, missing in the original description. This author rightly attributed the species to the genus Hollinella.

In 1964, Ishizaki assigned specimens discovered in the Early Pennsylvanian (Late Carboniferous) of Japan to Hollinella tingi. The preservation of the figured specimen (Ishizaki, 1964: pl. 1, fig. 1) is so bad that it is quite impossible to confirm the assignment.

In 1978, Wang wrote that Hollinella tingi occurs in the Late Changhsingian and Early Induan of Western Guizhou and

Explanation of Plate 1.

figs 1-9. Reviya curukensis Crasquin-Soleau n. sp. (All specimens from Kokarkuyu Formation, Induan, Early Triassic): 1, holotype, left lateral view, collection number P6M1467, sample 02TK56; 2, dorsal view, collection number P6M1470, sample 02TK56; 3, paratype, right lateral view, collection number P6M1468, sample 02TK56; 4, paratype, left lateral view, collection number P6M1469, sample 02TK57; 5, right lateral view, collection number P6M1471, sample 02TK58; 6, left lateral view, collection number P6M1472, sample 02TK55bis; 7, left lateral view, collection number P6M1473, sample 02TK56; 8, left lateral view, collection number P6M1474, sample 02TK118; 9, right lateral view, collection number P6M1475, sample 02TK58. fig. 10. Paraparchitacea gen. and sp. indent, left lateral view, collection number P6M1476, sample O2TK118, Kokarkuy Formation, Induan, Early Triassic. fig. 11. Callicythere sp., right lateral view, collection number P6M1477, sample 02TK47, Pamucak Formation, Capitanian-Changhsingian, Middle-Late Permian. fig. 12. Liuzhinia $\mathrm{cf}$. parva Wei 1981, right lateral view, collection number P6M1478, sample 02TK46, Pamucak Formation, Capitanian-Changhsingian, Middle-Late Permian. figs 13-14. Bairdia subsymmetrica (Shi 1987) (specimens from Kokarkuyu Formation, Induan, Early Triassic, sample 02TK57): 13, right lateral view, collection number P6M1479; 14, right lateral view, collection number P6M1480. Scale bar for all figures is $100 \mu \mathrm{m}$. All specimens come from the Çürük dağ section, Antalya Nappes, Taurus, Turkey, $\mathrm{N} 36^{\circ} 41^{\prime} 32-\mathrm{E} 30^{\circ} 27^{\prime} 40$. Specimens are stored in the Pierre et Marie Curie University Collection, Paris, France. 


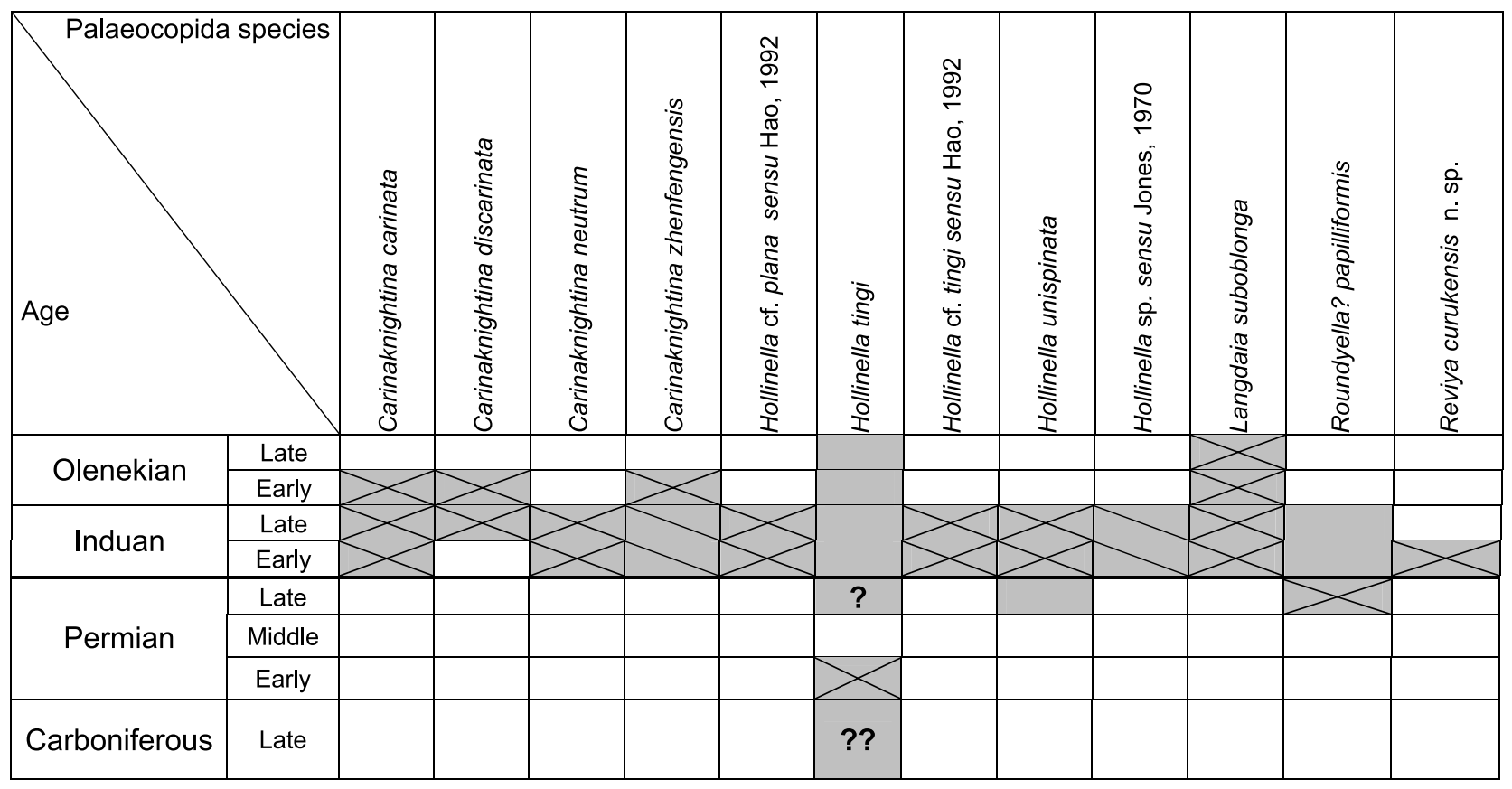

Grey boxes, occurrence in reference list; crossed boxes, occurrence considered as valid in this paper.

Table 3. Revised distribution of Early Triassic palaeocopid species.

Northeastern Yunnan. The figured specimens (Wang, 1978: pl. 1, figs 5-7) are relatively close to Hou's specimens. However, the specimen figured (pl. 1, fig. 6) has a higher ratio height/ length and a small node on L3; the specimens figured in Wang's pl. 1 (figs 5 and 7) show more arched L1 and the lobes are more rounded.

In 1981, Wei figured (pl. 1, figs 1-3) three specimens from the Induan-Olenekian of Sichuan, assigned to Hollinella tingi. The first two (Wei, 1981: pl. 1, figs 1 and 2) are very badly preserved and the assignment must be considered dubious. The specimen figured in Wei (1981: pl. 1, fig. 3) shows an anterior border very different (on this specimen the curvature radius is definitely shorter) than the Patte (1935) \& Hou (1954) specimens.

In 1985a (pl 13, fig. 3), Kozur figured a corroded and abraded specimen from the Werfenian (Induan) of the Bükk Mountains (Hungary). It is impossible to give this specimen an assignment at the species level. Furthermore, it is not reasonable to use this species as a stratigraphic index for the Permian-Triassic boundary as suggested by that author.

In 1987, Shi \& Chen figured specimens of Hollinella tingi from the Early and Middle Changhsingian of Meishan section. The specimen figured (pl. 16, fig. 2) is close to the type species and seems to present the cardinal spines. The three other specimens (Shi \& Chen, 1987: pl. 16, figs 2-5) are very badly preserved and/or broken and could not be assigned. Shi \& Chen (1987) studied all the Changhsingian and did not report the species from the upper part of the section.

Hao (1992, 1994) described specimens of Hollinella tingi found in the Induan of Guizhou. The specimens figured in 1992 (Hao: pl. 1, figs 5-6) do not belong to Hollinella tingi. The first one has a very different lateral outline (pl. 1, fig. 5) and the second one (pl. 1, fig. 6) shows strong reticulation in front of L1 and seems to have a ventral ridge. In 1994, Hao figured ostracods from the Permian-Triassic interval. Hollinella tingi from the Triassic (Hao, 1994: pl. 1, fig. 2) is the same picture as in the 1992 paper; the Permian specimen (pl. 1, fig. 6) is close to the type species but it shows a strong punctuation and the cardinal spines are not visible.

In conclusion, Hollinella tingi occurs in the Early Permian (Patte, 1935; Hou, 1954). It could occur in the Late Permian (Shi \& Chen, 1987). Its presence in the Late Carboniferous is very doubtful (Ishizaki, 1964). The species is not present in the Triassic.

In 1992, Hao described Hollinella unispinata from the Induan of Guizhou (South China). In 1994, Hao displayed the occurrence of Hollinella unispinata in the Late Permian but without explanation or figures. He repeated this for Roundyella? papilliformis described by Wang in 1978 in the Late Permian from Western Guizhou and Northeastern Yunan, i.e. he put an occurrence in the Early Triassic without explanation. So the range of the two species across the Permian-Triassic boundary has not yet been proven.

Worthy of note is the indisputable occurrence of the genus Hollinella in the Early Triassic (Jones, 1970; Wang, 1978; Wei, 1981; Kozur, 1985a; Hao, 1992, 1994).

The ostracod fauna discovered in the Çürük dağ section provides new data, with 28 species occurring in the Late Permian and 12 in the earliest Triassic (Table 4). Concerning the Palaeocopida, the occurrence of the new species Reviya curukensis proves the survival of this genus into the Triassic. One specimen, badly preserved, seems to belong to Paraparchitacea (Pl. 1, fig. 10), which be confirmed by further study.

Two Triassic genera, Callicythere (Cytheracea) and Liuzhinia (Bairdiacea) (Pl. 1, figs 11-12), are recognized for the first time 


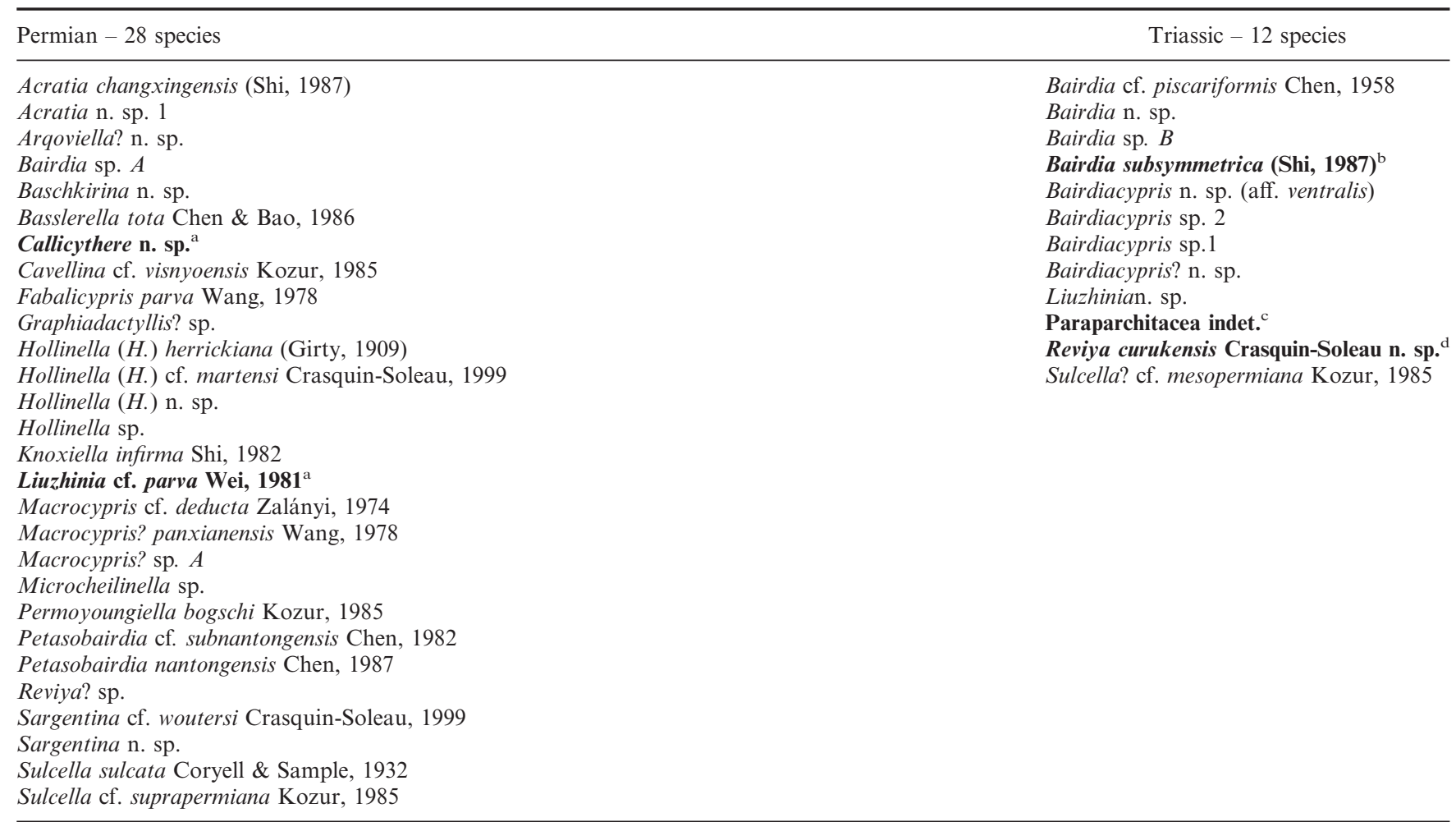

${ }^{a}$ Triassic genera recognized for the first time in Late Palaeozoic.

${ }^{\mathrm{b}}$ Species which survive to Permo-Triassic events.

${ }^{\mathrm{c}}$ First occurrence of the superfamily in Triassic.

${ }^{\mathrm{d}}$ Late Palaeozoic genus recognized for the first time in Triassic.

Table 4. Ostracod species of the Çürük dağ section near the Permian-Triassic boundary.

in the Permian. One species of Bairdiacea crosses the PermianTriassic boundary in the Çürük dağ section, namely Bairdia subsymmetrica (Shi, 1987) (Pl. 1, figs 13-14).

\section{CONCLUSIONS}

As yet there is no conclusive evidence to show that individual species of Palaeocopida range across the Permian-Triassic boundary, although it is known that some genera do so (e.g. Hollinella, Carinoknightina and Reviya). To date, 12 species of Palaeocopida are known from lowermost Triassic sediments. It is also possible that members of the Paraparchitacea may survive into the earliest Triassic but this has yet to be proven with certainty.

Three non-palaeocopid Permian species are known to occur in the Early Mesozoic - Fabalicypris reniformis (Chen, 1958), Bairdia subsymmetrica (Shi, 1987), both belonging to Bairdiacea, and Basslerella obessa Kellett, 1935 (Cytheracea). This study revises upwards the ostracod species extinction rate evaluated by Lethiers (1998) for the Permian-Triassic boundary, from $93 \%$ to $98 \%$.

\section{ACKNOWLEDGEMENTS}

The authors are very grateful to Dr Ian Boomer for his very constructive remarks and for his patience with the English of the first author. The two other anonymous reviewers are also thanked for their help in the improvement of the paper.

\section{APPENDIX A: TAXONOMY}

Order Palaeocopida Henninsgmoen, 1953

Suborder Kirkbyocopina Gründel, 1969

Superfamily Kirkbyacea Ulrich \& Bassler, 1906

Family Kirkbyidae Ulrich \& Bassler, 1906

Genus Reviya Sohn, 1961

Reviya curukensis Crasquin-Soleau n. sp.

$$
\text { (P1. 1, figs 1-9) }
$$

2002 Reviya? sp. 1. Crasquin-Soleau et al: 493, figs 4.6-4.8.

Derivation. From the type locality, Çürük dağ section.

Diagnosis. Species of Reviya with posterior border showing smaller curvature radius than anterior border; and reticulation free of anastomosing ridges.

Holotype. One complete carapace (Pl. 1, fig. 1), collection number P6M1467.

Paratypes. Two complete carapaces (Pl. 1, figs 3-4), collection numbers P6M1468 and P6M1469. 


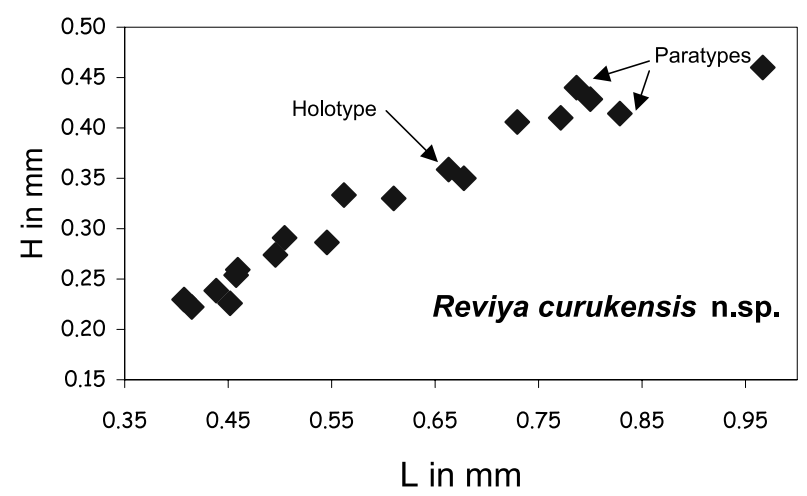

Fig. A1. Height-length diagram of Reviya curukensis Crasquin-Soleau n. sp.

Material. Nineteen carapaces, 15 valves and numerous fragments.

Type level. Sample 01TK56, Hindeodus parvus-Isarcicella isarcica Zone, Early Induan.

Type locality. N3641’32-E30²7’40, Çürük dağ section, Antalya Nappes, Taurus, Turkey.

Description. Species of Reviya (Kirkbyidae with straight-backed sub-elliptical tumid reticulated carapace without nodes or carinae and with elongate sub-central pit; Sohn, 1961: 141; rewritten by Becker, 1997: 161); right valve larger than left; overlapping along all free margins; anterior border regularly arched with radius of curvature larger than posterior; ventral border slightly concave in median part, stronger on left valve; carapace slightly compressed in antero-ventral part; presence of a smooth and narrow marginal ridge.

Dorsal view biconvex, right valve larger than left; slight depression at pit; maximum width near mid-length; hinge line straight; more compressed than the other species of the genus.

Surface punctuated; sub-central elongated kirkbyian pit, located at the lower third of height.

Comparisons. Reviya curukensis n. sp. seems to be closely comparable to Reviya mimicus (Geis, 1932) from the Late Mississippian of Indiana from which it differs by it smaller width and its posterior border being less high than the anterior one. It differs from the type species Reviya obesa (Croneis \& Gale, 1932) by the absence of the reticulation formed by anastomosing ridges sub-parallel to free margins.

Dimensions. Adults: $\mathrm{L}=0.55-0.97 \mathrm{~mm} ; \quad \mathrm{H}=0.29-0.46 \mathrm{~mm}$; $\mathrm{W}=0.30-0.49 \mathrm{~mm}$ (see Fig. A1).

Occurrence. Induan of the Çürük dağ section, Antalya Nappes, Taurus, Turkey; Kokarkuyu Formation, Induan, Early Triassic. Marine.

Stratigraphic remarks. The genus Reviya Sohn, 1961 is known in the Late Mississippian (Early Carboniferous). The Early Triassic occurrence of Reviya curukensis n. sp. extends the stratigraphic range of the genus from the Late Mississippian up to the Early Triassic. Another Reviya species is present in the Late Permian of the Çürük dağ section (Crasquin-Soleau et al., in press).

\section{Manuscript received 29 April 2003 Manuscript accepted 23 January 2004}

\section{REFERENCES}

Agarwal, P.N. 1979. Scythian Ostracodes from the 'Khunamuh Formation', Khreuh, Kashmir Himalayas. Current Sciences, 48(10): 442-443.

Agarwal, P.N. 1980. A record of Lower Triassic Ostracodes from Guryul Ravine, Kashmir. Geoscience Journal, 1(1): 93-94.

Agarwal, P.N. 1981. An account of marine Triassic Ostracodes and their possible utility in biostratigraphy, with special reference to Judahella Sohn, in certain Lower Triassic sections in Kashmir Himalaya. Proceeding of IX Indian Colloquia Micropaleontology and Stratigraphy. Science University, Bangalore, 146-155.

Angiolini, L., Balini, M., Garzanti, E., Nicora, A., Tintori, A., Crasquin, S. \& Muttoni, M. 2003. Permian climatic and paleogeographic changes in Northern Gondwana: the Khuff Formation of Interior Oman. Palaeogeography, Palaeoclimatology, Palaeoecology, 191: 269-300.

Becker, G. 1997. The superfamily Kirkbyacea Ulrich \& Bassler, 1906. 3. Family Kirkbyidae Ulrich \& Bassler, 1906. Neues Jahrbuch für Geologie und Palaontologie Abhandlungen, 205(2): 159-175.

Becker, G. \& Wang, Shang-qi 1992. Kirkbyacea and Bairdiacea (Ostracoda) from the Palaeozoic of China. Palaeontographica, A, 224(1-2): 1-54.

Belousova, Z.D. 1965. Class Crustacea, Subclass Ostracoda. In: Ruzhenstsev, N.E. \& Sarytcheva, T.G. (Eds), Evolution and succession of organisms at the Paleozoic-Mesozoic boundary. Trudy Paleontologichesnogy Instituta Akademia Nauk SSSR, 108: 83-85, 254-265 (in Russian).

Benton, M.J. 1995. Diversification and Extinction in the History of Life. Science, 268: 5258.

Bless, M.J.M. \& Jordan, H. 1972. Ostracodes of the Family Hollinellidae. Mededelingen Rijks Geologische Dienst. Serie C, 3(1): $1-155$.

Broglio Loriga, C., Neri, C., Pasini, N. \& Posenato, R. 1986. Marine fossil assemblage from Upper Permian to Lowermost Triassic in the Western Dolomites (Italy). Memoria della Società Geologica Italiana, 34: $5-44$.

Chao, King-koo 1965. The Permian ammonoid-bearing formations of South China. Scientia Sinica, 14(12): 1813-1825.

Chen, De-qiong \& Shi, Cong-guang 1982. Latest Permian Ostracoda from Nantong, Jiangsu and from Mianyang, Hubei. Bulletin Nanjing Institut of Geology and Palaeontology, Academia Sinica, 4: 105-152 (in Chinese).

Crasquin-Soleau, S. 2003. A new ostracode (Crustacea) species (Geffenina wangi) from the Middle Permian of the Jebel Gharif (Central Oman). Journal of Micropalaeontology, 22(1): 101-105.

Crasquin-Soleau, S. \& Baud, A. 1998. New Permian ostracods from Greece (Hydra Island). Journal of Micropalaeontology, 17: 131-152.

Crasquin-Soleau, S., Broutin, J. \& Roger, J. 1999. First Permian ostracode fauna from the Arabian Plate (Khuff Formation, Sultanate of Oman). Micropaleontology, 45(2): 163-182.

Crasquin-Soleau, S., Broutin, J., Besse, J. \& Berthelin, M. 2001. Ostracods and palaeobotany from the Middle Permian of Oman: implications on Pangaea reconstruction. Terra Nova, 13(1): 38-43.

Crasquin-Soleau, S., Richoz, S., Marcoux, J., Angiolini, L., Nicora, A. \& Baud, A. 2002. Les événements de la limite Permien - Trias: derniers survivants et/ou premiers re-colonisateurs parmi les ostracodes du Taurus (Sud-Ouest de la Turquie). Comptes Rendus Geosciences, Paris, 334: 489-495.

Crasquin-Soleau, S., Marcoux, J., Angiolini, L., Nicora, A. \& Bertho, Y. in press. A new ostracode fauna from the Permian-Triassic boundary in Turkey (Taurus, Antalya Nappes). Micropaleontology.

Erwin, D.H. 1993. The great Paleozoic crisis: life and death in the Permian. Columbia University Press, New York, 327pp. 
Erwin, D.H. 1998. The end and the beginning: recoveries from mass extinctions. Trends in Ecology and Evolution, 13(9): 344-349.

Gerry, E., Honingstein, A., Derin, B. \& Flexer, A. 1987. Late Permian Ostracodes of Israel. Taxonomy, distribution and paleogeographical implications. Senckbergiana lethaea, 68(1/4): 197-223.

Gramm, M.N. 1997. Ostracodes of the Chandalaz horizon (Upper Permian) of South Primorye. In: Baud, A., Popova, I., Dickins, J.M. Lucas, S. \& Zakharov, Y. (Eds), IGCP Project 272: Late Paleozoic and Early Mesozoic Circum-Pacific events: Biostratigraphy, tectonic and ore deposits of Primoryie (Far East Russia). Mémoires de Géologie, Lausanne, 30: 61-71.

Hamilton, I.B. 1942. Ostracodes from the Upper Permian of Texas. Journal of Paleontology, 16(6): 712-718.

Hao, Wei cheng 1992. Early Triassic marine Ostracods from Guizhou. Acta Micropalaeontologica Sinica, 9(1): 37-44 (in Chinese).

Hao, Wei cheng 1994. The development of the Late Permian-Early Triassic ostracod fauna in Guizhou Province. Geological Review, 40(1): 87-92 (in Chinese).

Hirsch, F. \& Gerry, E. 1974. Conodont- and ostracode biostratigraphy of the Triassic in Israel. Schriftenreihe der erdwissenschaftlichen Kommissionen, Österreichische Akademie der Wissenschaften, Wien, 2: $107-114$

Horne, D.J., Cohen, A. \& Martens, K. 2002. Taxonomy, Morphology and Biology of Quaternary and living Ostracoda. In: Holmes, J.A. \& Chivas, A. (Eds), The Ostracoda: applications in Quaternary Research. Geophysical Monograph, 131: 5-36.

Hou, You-tang 1954. Some Lower Permian ostracods from Western Hupei. Acta Palaeontologica Sinica, 2(2): 227-266.

Ishizaki, K. 1964. Middle Permian Ostracodes from the Iwaizaki Limestone, Northeast Japan. Science reports of the Tohoku University, Sendai, 36(1): 139-160.

Ivanov, V.K. 1975. Ostracodes. In: Suveizdisa, P.I. (Ed.), Permian deposits of Baltic area (Stratigraphy and fauna). Trudy Litovskii Nauchno Issledovateliskii Geologorazvedochnii Institut, 29: 156-184

Jablonski, D. 1994. Extinctions in the fossil record. Philosophical Transactions of the Royal Society of London, B344: 11-17.

Jones, P.J. 1970. Marine Ostracoda (Palaecopa, Podocopa) from the Lower Triassic of the Perth Basin, Western Australia. Bulletin of Bureau of Mineral Resources, Geology and Geophysics, 108 115-142.

Khivintseva, E.A. 1969. New ostracods from the Kazanian deposits of Orenburg province. Paleontological Journal, 1: 95-104 (in Russian).

Knüpfer, J. 1967. Zur Mikrofauna aus dem unteren Teil des Zechstein von Rügen. Freiberger Forschungshefte, C213: 73-87.

Kolar-Jurkovšek, T. \& Jurkovšek, B. 1995. Lower Triassic conodont fauna from Trzic (Karavanke Mts, Slovenia). Eclogae geologia Helvetica, 88(3): 98-801.

Kotschetkova, H.M. 1959. Ostracoda of the Lower Kazanian substage of Western Bashkiria. In: Geological questions on Eastern Russian Platform and Southern Urals. Akademia Nauk SSSR Bashkirinskiy Fibid, Gorus-Geologicheskiy Institut, 2: 1-36 (in Russian).

Kozur, H. 1971. Die Bairdiacea der Trias. Teil 3: Einige neue Arten triassischer Bairdiacea und Bemerkungen zur Herkunft der Macrocyprididae (Cypridacea). Geologisch-Paläontologische Mitteilungen Innsbruck, 1(6): 1-18.

Kozur, H. 1972. Einige Bemerkungen zur Systematik der Ostracoden und Beschreibung neuer Platycopida aus der Trias Ungarns und der Slowakei. Geologisch-Paläontologische Mitteilungen Innsbruck, 2(10): $1-27$.

Kozur, H. 1985a. Biostratigraphic evaluation of the Upper Paleozoic conodonts, ostracods and holothurian sclerites of the Bükk Mts. Part II: Upper Paleozoic ostracods. Acta Geologia Hungarica, 28(3-4): 225-256.

Kozur, H. 1985b. Neue Ostracoden - Arten aus dem Oberen Mittelkarbon (Höheres Moskovian), Mittel- und Oberperm des Bükk- Gebirges (N- Ungarn). Geologisch-Paläontologische Mitteilungen Innsbruck, 2 $1-145$.

Kozur, H. 1991. Permian deep-water ostracods from Sicily (Italy). Part 1: Taxonomy. Geologisch-Paläontologische Mitteilungen Innsbruck, $\mathbf{3}$ $1-24$

Kozur, H. 1993. Relation between Late Paleozoic-Triassic Kirkbyacea and Cretaceous-Recent Punciacea (Ostracoda). In: McKenzie, K.G
\& Jones, P.J. (Eds), Proceedings of the $11^{\text {th }}$ International Symposium on Ostracoda, Australia. Balkema, Rotterdam, 91-106.

Kozur, H. 1998. Upper Triassic Punciacea, the connecting link between the Palaeozoic to Lower Triassic Kirkbyacea and the Cretaceous to Cenozoic Punciacea. In: Crasquin-Soleau, S., Braccini, E. \& Lethiers, F. (Eds), What about Ostracoda! Actes du 3e Congrès Européen des Ostracodologistes. Bulletin Centre Recherche Elf Exploration et Production Mémoire, 20: 257-269.

Krömmelbein, K. 1958. Ostracoden aus dem unteren Zechstein der Bohrung Leba in Pommern. Geologische Jahrbuch, 75: 115-135.

Kukhtinov, D.A. \& Crasquin-Soleau, S. 1999. Upper Permian and Triassic of the Precaspian Depression: stratigraphy and palaeogeography. In: Crasquin-Soleau, S. \& De Wever, P. (Eds), Peri-Tethys stratigraphic correlations 3. Geodiversitas, 21(3): 325-346.

Lai, Xulong \& Mei, Shilong 2000. On zonation and evolution of Permian and Triassic conodonts. In: Yin, Hongfu, Dickins, J.M. \& Tong, Jinnan (Eds), Permian-Triassic evolution of Tethys and Western Circum-Pacific. Development in Paleontology and Stratigraphy, 18. Elsevier, Amsterdam, 371-392.

Lethiers, F. 1998. Évolution de la biosphère et événements géologiques. Gordon and Breach Science Publishers, Amsterdam, 321pp.

Lethiers, F., Razgallah, S., Colin, J.P. \& Vachard, D. 1989. Micropalaeontology of the Permian Marls of Merbah el Oussif (Jebel Tebaga, Tunisia) with special emphasis on the Ostracods. Journal of Micropaleontology, 8(2): 227-238.

Lys, M. \& Marcoux, J. 1978. Les niveaux du Permien supérieur des Nappes d'Antalya (Taurides occidentales, Turquie). Comptes Rendus de l'Académie des Sciences Paris, 286: 1417-1420.

Marcoux, J. \& Baud, A. 1986. The Permian-Triassic boundary in the Antalya Nappes (Western Taurides, Turkey). Memorie della Società Geologica Ialiana, 34: 243-252.

Moore, R.C. 1961. Arthropoda 3. Crustacea, Ostracoda. Geological Society of America and University of Kansas Press, Q1-Q442.

Olempska, E. \& Blaszyk, J. 1996. Ostracods from Permian of Spitsbergen. Polish Polar Research, 17(1-2): 3-20.

Patte, E. 1935. Fossiles paléozoïques et mésozoïques du Sud Ouest de la Chine. Palaeontologica Sinica, Serie B, 15(2): 1-50.

Rong, Jia-yu \& Shen, Shu-zhong 2002. Comparative analysis of the end-Permian and end-Ordovician brachiopod mass-extinctions and survivals in South China. Palaeogeography, Palaeoclimatology, Palaeoecology, 188(1-2): 25-38.

Schneider, G.F. 1948. Late Permian (Tatarian and Kazanian stages) ostracod fauna from oil fields in USSR. Microfauna of oil fields of USSR, Bakou (Central Asia) and Western Siberia, 1: 21-26 (in Russian).

Schneider, G.F. 1960. The ostracod fauna from the Lower Triassic deposits of the Lowlands situated near the Caspian Sea. Geology of USSR oil field, Turkmenistan and Kazakhstan. Trudy Academy of Sciences of USSR Bulletin: 287-303 (in Russian).

Sepkoski, J.J.Jr 1992. A compendium of fossil marine families 2 nd edition. Milwaukee Public Museum Contribution in Biology and Geology, 83: 1-156.

Shi, Cong-guang \& Chen, De-qiong 1987. The Changhsingian ostracodes from Meishan, Changxing, Zhejiang. In: Stratigraphy and Palaeontology of Systemic boundaries in China, Permian and Triassic boundary. University Press House, 23-80 (in Chinese).

Sohn, I.G. 1961. Aechminella, Amphissites, Kirkbyella, and related genera. Geological Survey Professional Paper, 330: 107-160.

Sohn, I.G. 1970. Early Triassic Marine Ostracodes from the Salt Range and Surghar Range, West Pakistan. In: Kummel, B. \& Teichert, C. (Eds), Stratigraphic boundary problems: Permian and Triassic of Western Pakistan. University of Kansas, Department of Geology Special Publication, 4: 193-206.

Tozer, E.T. 1967. A standard for Triassic Time. Bulletin Geological Survey of Canada, 156: 1-103.

Twitchett, R.J. 1999. Palaeoenvironments and faunal recovery after the end-Permian mass extinction. Palaeogeography, Palaeoclimatology, Palaeoecology, 154(1-2): 27-37.

Wang, Shang-qi 1978. Late Permian and Early Triassic ostracods of Western Guizhou and Northeastern Yunnan. Acta Palaeontologica Sinica, 17(3): 277-312 (in Chinese). 
Waterhouse, J.B. 1997. The Permian Time scale. Permophiles. $A$ newsletter of the Subcommission on Permian Stratigraphy, 30: 6-8.

Wei, Ming 1981. Early and Middle Triassic Ostracods from Sichuan. Acta Palaeontologica Sinica, 20(6): 501-507 (in Chinese).

Woszczynska, S. 1987. Foraminifera and ostracods from the carbonate sediments of the Polish Zechstein. Acta Palaeontologica Polonica, 32(3-4): 155-205.
Zalanyi, B. 1974. Die oberpermischen Ostracoden des Bükk Gebirges. In: Sido, M. (Ed.), Neue paläontologische Ergebrisse aus dem Oberpaläozoïkum des Bükk-Gebirges. Akademia Kiado, Budapest, 95-251.

Zheng, Shuying 1976. Early Mesozoic ostracods from some localities in South West China. Acta Palaeontologica Sinica, 15(1): 77-93 (in Chinese). 